\title{
Performance Assessment of Solar Powered Smart Drip Irrigation System using Arduino
}

\author{
P. Lenin Pugalhanthi, R. Senthil Kumar, B. Rajesh Kumar, E. Sneha
}

\begin{abstract}
In the agriculture field, the method of irrigation and its proper usage is more important and it is well known that a very economical and efficient method is drip irrigation. The continuous monitoring of the soil and weather condition has to be done by the farmer in favour of growth of crops in conventional drip irrigation system. In this proposed system, the soil and weather condition of the field are monitored by the moisture as well as temperature sensor. The values from the temperature and moisture sensors are sensed and the signal is sent to the Arduino IDE controller which is powered by solar energy and thus the present values are compared with predefined values. According to value of the temperature and moisture, the crops can be supplied with the required amount of water. In the liquid crystal display, the sensed values of the temperature and moisture will be displayed and the user can receive the data through the GSM module.
\end{abstract}

Keywords: Ardunio, GSM, Moisture sensor, Solar panel, Temperature sensor

\section{INTRODUCTION}

In food production technology, demand of the food is increasing continuously which needs advanced technology for monitoring and production. In India, agriculture and the climatic conditions is the main reason for economy, which are isotropic even though we are not utilization the full agricultural resources [1]. Unplanned use of water is a another very important reason, due to this reason more amount of water will be wasted. Water is supplied near the root of the plants by the way of drip by drip due to which a large amount of water can be saved in the modern drip irrigation systems which is one of the most significant advantage [2]. In India at present, the farmers are using irrigation technique by the manual process in which the land can be irrigated by the farmers at the regular intervals. Sometimes the consumption of water is more or sometimes the water reaches the crop very late, due to these reasons the crops may dried during this process. The rate of the growth is slowed, lighter weight fruit

Revised Manuscript Received on December 12, 2019

* Correspondence Author

P. Lenin Pugalhanthi*, Electrical and Electronics Engineering department, Sri Krishna College of Technology,Kovaipudur, Coimbatore, Tamilnadu, India. Email: leninpugal@ skct.edu.in

R. Senthil Kumar, Electrical and Electronics Engineering department, Sri Krishna College of Technology,Kovaipudur, Coimbatore, Tamilnadu, India. Email: senthilkumar.r@ skct.edu.in

B. Rajesh Kumar, Department of Electronics and Communication Engineering, M. Kumarasamy College of Engineering, Karur, India Email: rajuae2011@gmail.com

E. Sneha, Electrical and Electronics Engineering department, Srì Krishna College of Technology,Kovaipudur, Coimbatore, Tamilnadu, India. Email: snehasasikala@gmail.com follows slight water deficiency. We can use automatic drip-irrigation using microcontroller to solve this problem in which the process will take place only when the crop requires water in [3].

The valves are used in irrigation system to turn irrigation ON and OFF. By using controllers, these valves can be easily automated. Farmers can apply the right amount of water at the right time in automatic farm, regardless of the availability of labour to turn valves on and off. One of the valuable tools for accurate control of soil moisture is automatic drip irrigation in high production and a simple, precise method for irrigating the field using sensors in [4]-[8].

\section{SYSTEM DESCRIPTION}

The solar panel is placed to utilize the solar power for irrigation system and also store the solar power in battery to make the system fully automated. The important parameters such as soil moisture and temperature are to be measured for automation of irrigation system. The small sections are divided from the entire field such that moisture sensor and a temperature sensor are placed in each section. The moisture content of soil is detected using the soil moisture sensor. The above sensors can be placed at different areas in the agriculture field. Figure.1. shows the Schematic circuit diagram of three phase shunt active power filter connected with grid system[9]

Moisture sensors are buried at required depth. The sensors send a information to the controller when the soil has reached the desired moisture level. The controller receives the signal from the sensor if the moisture content of the agriculture field gets minimized. Water from the source is pumped using the pump which is placed at the storage tank. In the liquid crystal display, the sensed values from the sensor will be displayed and the user can receive the data through the GSM module in the monitor field. The root of the plant is supplied with drop by drop water[10]. The sensor gives corresponding signal to the controller once it reaches the desired moisture level. Hence the crop has high yield with low usage of water.

\section{SELECTION OF CROPS, SOIL AND WATER}

\section{A. Suitable crops}

Vegetation such as row crops (vegetables, soft fruit), tree and vine crops are most suitable for drip irrigation where each plant is provided with one or more emitters. Generally,Due to high capital cost, only high value crops are considered for installing a drip system [11]. 


\section{Performance Assessment of Solar Powered Smart Drip Irrigation System using Arduino}

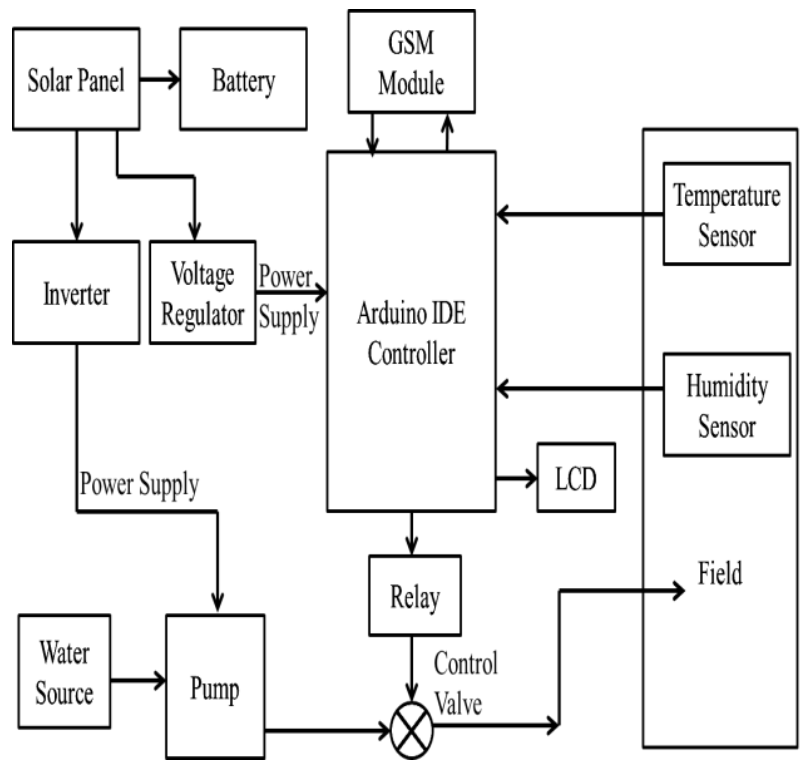

Figure 1. Block diagram of smart drip irrigation system

\section{B. Soils Selection}

In order to avoid surface water ponding and run off in clay soils, water must be applied slowly. In order to ensure sufficient lateral soil moisture in sandy soils, higher emission levels will be required.

\section{Suitable Irrigation Water}

Blocking the emitters is one of the main problems with drip irrigation. Both emitters have water paths ranging from $0.2-2.0 \mathrm{~mm}$ in diameter, which is very small, and if the water is not clear, these emitters will be blocked. Thus, the irrigation water is essential to be free from sediments. Irrigation water filtration will be required if water is not suitable for agriculture.

- If the water contains any algae, fertiliser bonds and dissolved precipitating chemicals, like calcium and iron, can lead to blockage. Some of the contaminants may be eliminated by filtration, but the issue may be difficult to solve and an experienced engineer or equipment dealer is expected to consult.

- Saline water (poor quality water) is particularly suitable drip irrigation. An efficient method to use water is dripping water to the plants. For this purpose, drip irrigation is most effective when water is infrequent.

\section{Study of Crops}

Requirements for the growth of different crops have been studied at various seasons. The growth of the crop is influenced by two basic parameters such as temperature and moisture. Hence both of the parameters are more important. Different temperature and moisture levels are required by each crop at various stages. But parameters have an ideal range of values. If the soil temperature is increased, soil moisture will be decreased. Hence for the better yield of crops the comparison of these both parameters can be used[12].
Table1: optimum level of temperature and rainfall of various crops

\begin{tabular}{|l|l|l|l|}
\hline Crops & Growing Seasons & $\begin{array}{l}\text { Optimum } \\
\text { Temperature }\end{array}$ & $\begin{array}{l}\text { Optimum } \\
\text { Rainfall }\end{array}$ \\
\hline Rice & July - November & $22-30$ & $1000-1500$ \\
\hline Wheat & November-March & $16-22$ & $150-200$ \\
\hline Maize & March-June & $18-20$ & $400-500$ \\
\hline Millet & July-November & $16-20$ & $500-1500$ \\
\hline Barley & November-March & $7-14$ & $100-450$ \\
\hline
\end{tabular}

\section{E. Rice Crops}

Tropical and subtropical areas are best suited to rice crops that have a humid climate but are cultivated in a variety of climates, except for extreme cold temperatures. Rice production can be affected by climatic factors such as temperature, day length and moisture. The effect of atmospheric temperature on the growth and development of the rice plant is considered. For their optimum growth and development, rice requires relatively high temperatures. In rice, the optimum temperature range for grain-fill is between 20 and $25^{\circ} \mathrm{C}$. The amount of water required for the rice crop is between 1400 and $1800 \mathrm{~mm}$ of water. Therefore, when there is a lot of rain during the crop season, it will be sufficient for a well-distributed crop. The temperature and moisture of the rice crop is tabulated for the various seasons.

\section{F. Wheat Crop}

Crop which has a cool environment. Nevertheless, wheat crops require different temperatures at different stages of plant growth and development. Germination of seed decreases slowly when the temperature is below or above to the optimum temperature. At maturity time, if the temperature is more than $300 \mathrm{c}$, it may lead to a loss of strength and yield. Winter wheat treats cold waves and frosts better than spring wheat.

The wheat requires 12 to 15 inches (31 to $38 \mathrm{~cm}$ ) of water to produce a good crop. Wheat crop grows best when temperatures are between $70^{\circ}$ and $75^{\circ} \mathrm{F}\left(21^{\circ}\right.$ to $\left.24^{\circ} \mathrm{C}\right)$ but not too dry. It also needs a lot of sunlight, particularly when grain fills. Because many wheat diseases grow in moist weather, low humidity areas are better. The optimum moisture for wheat crop is $50-60 \%$. Moisture loss occurs due to heavy evapotranspiration and it results in more water requirement for irrigation when the relative moisture is less. When there is high moisture coupled

with high temperature then disease infestation will be increased.

The wheat crop has quite different temperatures. The ideal growing temperature of the wheat crop is between $10^{\circ} \mathrm{C}$ and $24^{\circ} \mathrm{C}$. The minimum temperature should not be less than $3^{\circ} \mathrm{C}$ and not exceed $33^{\circ} \mathrm{C}[13]-[14]$ 
Table 2: Water requirements and evaporation of the rice crop

\begin{tabular}{|c|c|c|c|c|c|}
\hline MONTH & $\begin{array}{l}\text { Augu } \\
\text { st }\end{array}$ & $\begin{array}{l}\text { Septe } \\
\text { mber }\end{array}$ & $\begin{array}{l}\text { Octo } \\
\text { ber }\end{array}$ & $\begin{array}{l}\text { Nove } \\
\text { mber }\end{array}$ & $\begin{array}{l}\text { Decemb } \\
\text { er }\end{array}$ \\
\hline $\begin{array}{l}\text { Mean } \\
\text { Temperatu } \\
\text { re }(\mathrm{K})\end{array}$ & 83.0 & 83.8 & 80.9 & 71.3 & 65.5 \\
\hline $\begin{array}{l}\text { Mean } \\
\text { Moisture } \\
(\%)\end{array}$ & 86.6 & 87.2 & 87.4 & 73.0 & 69.4 \\
\hline $\begin{array}{l}\text { Vapour } \\
\text { Pressure of } \\
\text { Water At } 2 \\
\text { Ft. Above } \\
\text { Water } \\
\text { Surface in } \\
\text { Rice Field } \\
(\mathrm{mm})\end{array}$ & 25.3 & 25.7 & 25.5 & 15.3 & 12.3 \\
\hline $\begin{array}{l}\text { Vapour } \\
\text { Pressure in } \\
\text { The Bulk } \\
\text { of Air at } \\
\text { Dew Point } \\
(\mathrm{mm})\end{array}$ & 21.6 & 22.5 & 20.6 & 10.5 & 7.8 \\
\hline $\begin{array}{l}\text { Mean } \\
\text { Velocity of } \\
\text { Wind At } \\
10 \mathrm{Ft} \\
\text { Above } \\
\text { Rice Field } \\
\text { (miles/hour } \\
\text { ) }\end{array}$ & 3.72 & 3.09 & 2.26 & 1.57 & 1.58 \\
\hline $\begin{array}{l}\text { Monthly } \\
\text { Evaporatio } \\
\text { n from } \\
\text { Rice Field } \\
\text { (Inches) }\end{array}$ & 3.01 & 2.29 & 3.23 & 2.80 & 2.77 \\
\hline
\end{tabular}

\section{G. Pearl Millet Crop}

The best temperature for growth of pearl millet is between $20-28^{\circ} \mathrm{C}$. It can survive under adverse climatic conditions. The growing areas of pearl millet crops are characterized by low soil fertility, drought as well as high temperature. It is also grown in low rainfall regions with annual rainfall of between 50 and $70 \mathrm{~cm}$. During its early vegetative period, moist weather is conducive to growth. It has a best growth at a temperature range of $20-30^{\circ} \mathrm{C}$. It can perform well in soils with high salinity or low PH. It may be grown in areas where other cereal crops, such as maize or wheat, would not survive because it could be tolerated under difficult growing conditions.

\section{H. Soil Moisture Sensor}

The soil moisture content can be determined by soil moisture sensors as shown in Fig.2. The popular soil moisture sensor type is a frequency domain sensor, such as a capacitance sensor for commercial use. The neutron moisture gauge is another sensor that uses the water moderator properties of neutrons[15]-[17].
Table 3: Water requirement and evapotranspiration of wheat crop

\begin{tabular}{|c|c|c|c|}
\hline $\begin{array}{c}\text { Stages } \\
\text { of } \\
\text { Crop } \\
\text { Develo } \\
\text { pment }\end{array}$ & $\begin{array}{c}\text { Gro } \\
\text { wth } \\
(\mathbf{m m}\end{array}$ & $\begin{array}{c}\text { Evapotran } \\
\text { spiration }\end{array}$ & $\begin{array}{c}\text { Water } \\
\text { Requir } \\
\text { ement } \\
(\mathbf{m m})\end{array}$ \\
\hline 1 & 2.7 & 672.2 & 1153 \\
\hline 2 & 2.62 & 609.1 & 1045 \\
\hline 3 & 2.66 & 639.2 & 1096 \\
\hline 4 & 2.67 & 594.4 & 1019 \\
\hline 5 & 2.7 & 416.6 & 714 \\
\hline 6 & 2.63 & 575.8 & 987 \\
\hline 7 & 2.66 & 673.5 & 1155 \\
\hline 8 & 2.69 & 546.4 & 937 \\
\hline 9 & 2.73 & 580.3 & 1002 \\
\hline
\end{tabular}

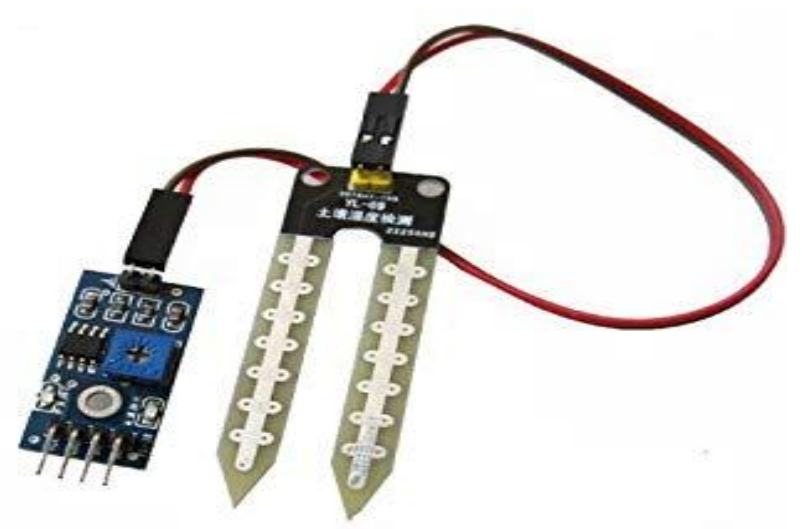

Figure 2. moisture sensor

\section{PUMP}

The pump has a life span of about 20,000 hours. It can sustain heavy duty work for a day and it is shown in Fig.3. It is waterproof and submersible and has a continuous operation. It is used for some indoor and outdoor applications.

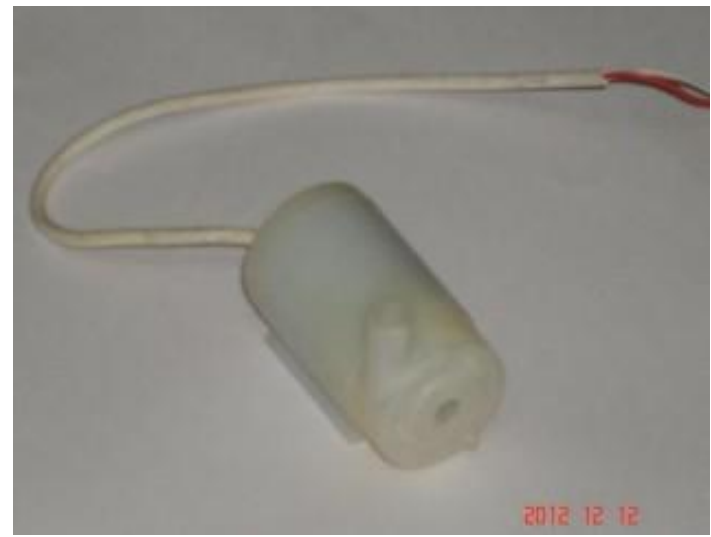

Figure 3. Pump

The input of the pump is +12 volt. The water get into the hole of the pump and easily it pumped to the field through sprinklers in the distributing tube[18]. 


\section{Performance Assessment of Solar Powered Smart Drip Irrigation System using Arduino}

\section{J. Relay Unit}

To turn on/off the pump, the relay is used along the transistor which is shown in Fig.4. Transistor BC547 is a switching device. The collector is permanently supplied with constant $12 \mathrm{~V}$ DC which supplies the relay voltage of the coil[19]-[21].

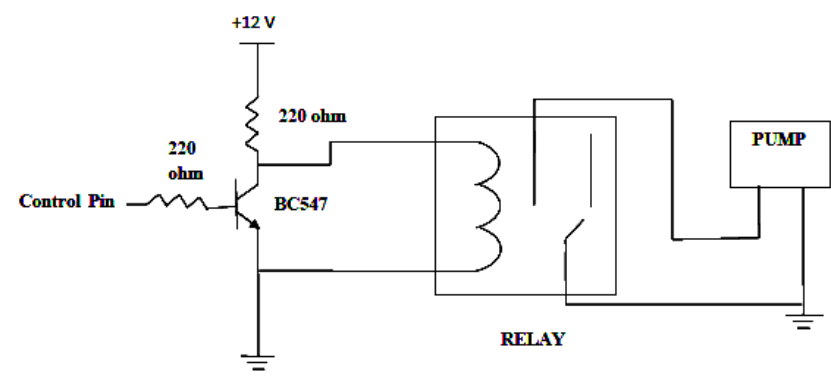

Figure. 4. circuit for Interfacing Pump with Relay Unit

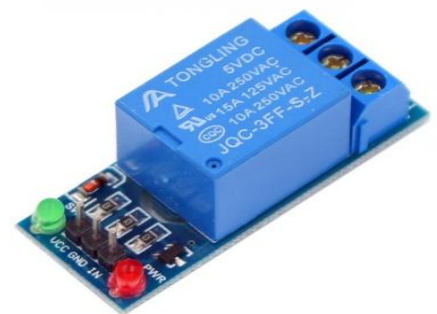

Figure 5:Relay module

Grounding has to be done in emitter. Turning on/off the relay can be done by the supply to the base of the transistor that ,When the supply is received, the relay is turned on and when the supply is cut off, the relay is switched off[22]. The load (pump) connected to the relay requires a supply voltage which should be given to the common pin. The Relay module is shown in Fig.5

\section{HARDWARE SETUP AND RESULTS}

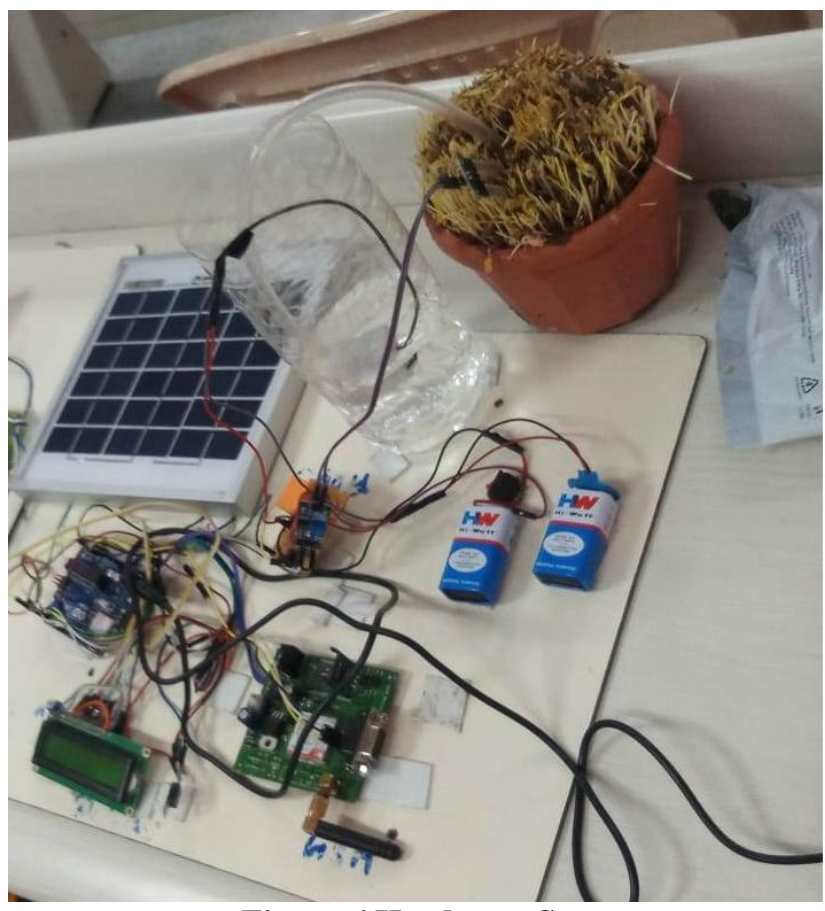

Figure 6.Hardware Setup
The hardware setup model is shown in Fig.6. The codings are fetched into Arduino controller and The plant moisture level is continuously monitored. When the soil moisture level is reached zero ,Automatically the water will be pumped into plant system using DC Pump. At the same time the alert message will be send through GSM module. The sample output with alert message is shown in Fig.7

Sunday, 21 Apr • 4:21 PM

\section{Moisture $\%=0.00$ Motor $\mathrm{ON}$}

\section{Moisture $\%=0.00$ Motor ON}

\section{Moisture $\%=0.00$ Motor $\mathrm{ON}$}

\section{$21 \mathrm{Apr}, 4: 21 \mathrm{PM} \cdot$ via airtel}

\section{Figure 7 .Sample Result}

\section{CONCLUSION}

The proposed method is used for the agriculture industries which can be modernized with optimum expenditure where the system is completely monitored and controlled all the activities of agricultural field using Arduino IDE controller efficiently. The soil moisture will be measured along with the surrounding area and the crop will be supplied with water to prevent water from clogging. In this method, the water is directly fed to the root and the quality of the crop is increased and the water can be saved easily. This reduces human error. Implementation on above subject will be processed for the various crops, soil at different weather condition in future. Using this obtained database, modernized drip irrigation will be controlled effectively.

\section{REFERENCES}

1. Das, Arka, et al. "Arduino Based Solar Powered Auto-Irrigation System." Available at SSRN 3350921 (2019).

2. Gage, Sandeep, et al. "Iot Based Solar Street Light Intensity Control System." (2019).

3. Syed, Kaleem. "Arduino based solar power inverter with battery charger controller with mobile interface." (2019). S.Devassyand B.Singh, "Design and Performance Analysis of Three-P

4. Negrete, Jaime Cuauhtemoc, et al. "Arduino board in the automation of agriculture in Mexico, a review." International Journal of Horticulture 8 (2018).

5. Guedes, Andre FS, et al. "Flexible organic photovoltaic solar cells applied in the educational platform Arduino." Nanoengineering: Fabrication, Properties, Optics, Thin Films, and Devices XVI. Vol. 11089. International Society for Optics and Photonics, 2019.

6. López-Vargas, Ascensión, Manuel Fuentes, and Marta Vivar. "IoT application for real-time monitoring of solar home systems based on Arduino $^{\mathrm{TM}}$ with 3G connectivity." IEEE Sensors Journal 19.2 (2018): 679-691.

7. Aniket, Kadam. "A Review Paper on Design and Development of Automatic Drip Irrigation System." (2018).

8. Rajasekhar, Dokka, and P. Prakash. "Automatic Drip Irrigation System through Iot." International Journal of Research 5.16 (2018): 85-88.

9. Chavda, Rohan, et al. "Smart Drip Irrigation System using Moisture Sensors." 2018 International Conference on Smart City and Emerging Technology (ICSCET). IEEE, 2018 . 
10. SenthilKumar, R., M. Ramesh, and K. Sunadararaju. "Design of Multi-Stack Voltage Equalizer For Partially Shaded PV Modules using Artificial Neural Network." International Journal of Control Theory and Applications 10 (2017): 1.

11. Kumar, Sandeep. Design and Evaluation of Automated Drip Irrigation System. Diss. Punjab Agricultural University, Ludhiana, 2018.

12. Ramesh, S., and K. P. Suresh. "Grid-Interconnected Solar Photovoltaic System for Power Quality Improvement Using Extended Reference Signal Generation Strategy." Journal of Testing and Evaluation 49.1 (2019).

13. Danita, M., et al. "IoT Based Automated Greenhouse Monitoring System." 2018 Second International Conference on Intelligent Computing and Control Systems (ICICCS). IEEE, 2018.

14. Senthilkumar, R., D. Rajkumar, and A. Mariya Sindhuja. "Sepic Based Multi-Stack Voltage Equalizer For Partially Shaded PV Modules Using Fuzzy Logic Controller." i-Manager's Journal on Power Systems Engineering 4.2 (2016): 38

15. Saravanan, S., et al. "Photovoltaic array reconfiguration to extract maximum power under partially shaded conditions." Distributed Energy Resources in Microgrids. Academic Press, (2019). 215-241.

16. Rajangam, K., Arunachalam, V.P. and Subramanian, R. "Profit Based Unit Commitment with Forecasted Power Demand Table", European Journal of Scientific Research, Vol.77 No.2, pp.221-230, 2012

17. Rajangam, K., S.V. Sreekanth Reddy, T.V. Santhosh ,Gopika Vinod, Shiju Varghes, Jay Shah., "Reliability Prediction of Seismic Switch for Early Detection of Earthquake at NPP Site", International Journal of System Assurance Engineering and Management- Springer. Vol.7, No.3, pp. 325-331, 2016

18. Kumar P.S., Gayathri R., Senthamarai C., Priyadharshini M., Fernando P.S.A., Srinath R., Kumar V.V. Kinetics, mechanism, isotherm and thermodynamic analysis of adsorption of cadmium ions by surface-modified Strychnos potatorum seeds Korean Journal of Chemical Engineering .vol 29 issue 12 pp 1752- 1760,2012

19. Bhuvaneswari K., Rauf H.A., Edgelet based human detection and tracking by combined segmentation and soft decision 2009 International Conference on Control Automation, Communication and Energy Conservation, 5204487 INCACEC 2009

20. Jameer Basha A., Palanisamy V., Purusothaman T. Efficient multimodal biometric authentication using fast fingerprint verification and enhanced iris features, Journal of Computer Science Vol 7 issue 5 pp 698706,2011

21. Punithavathani D.S., Sankaranarayanan K. IPv4/IPv6 transition mechanisms, European Journal of Scientific Research vol 34 ,issue 1,PP 110-124,2009

22. Sreeja N.K., Sankar A. Pattern matching based classification using Ant Colony Optimization based feature selection, Applied Soft Computing Journal VOL 31 issue 2818 PP 91-102,2015

\section{AUTHORS PROFILE}

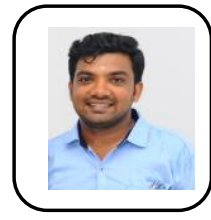

P. Lenin Pugalhanthi received UG degree from Maharaja Engineering college of Engineering, Avinasi, Tamilnadu. He received PG degree in the stream of Power Electronics and Drives from Sri Krishna .College of Engineering and Technology, Coimbatore, Tamilnadu. He attaneded more number of conferences and presented more papers in the field of power electronics and renewable energy sources. Currently he is working as a Assistant professor in Sri Krishna College of Technology, Coimbatore, Tamilnadu. His area of interest is in the field of Hybrid Electric Vechicles, Renewable Energy Sources and Intelligent Techniques

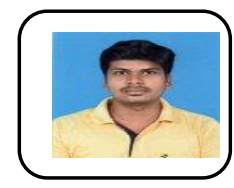

R. Senthil kumar got UG degree from PSNA college of Engineering, Dindigul, Tamil nadu. He got PG degree from the same college. He attended more conferences and presented more reputed papers in the field of Power Electronics and Drives. Currently he is working as an Assistant Professor in Sri Krishna College of Technology, Coimbatore. His interest is in the field of Power electronics control, soft computing techniques and AC Drives.

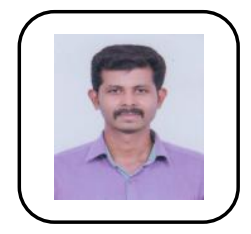

B. Rajesh Kumar received UG degree from V.S.B Engineering College, Karur, Tamil nadu. He got PG degree from Jayaram College of Engineering, Trichy, Tamil nadu. He attended more conferences and presented more reputed papers in the field of Applied Electronics and renewable energy sources. Currently he is working as an Assistant Professor in

M.Kumarasamy College of Engineering, Karur. His interest is in the field of Electronics Device, Renewable energy sources and Intelligent Techniques.

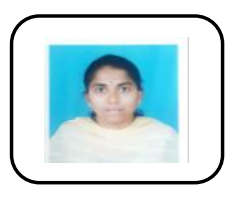

energy sources.
E. Sneha pursuing UG degree from Sri Krishna College of Technology, Coimbatore, Tamil nadu. She attended many workshops, conferences and presented more reputed papers in the field of Power Electronics and Drives. Her interest is in the field of Artifical Intelligences, Power System Protection and Renewable 